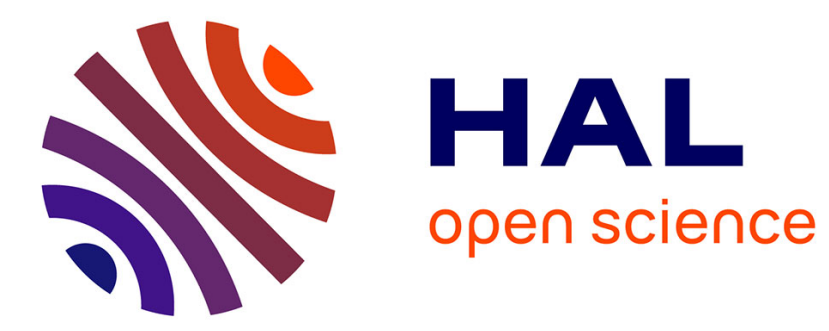

\title{
A proposal of clinical breakpoints for amoxicillin applicable to porcine respiratory tract pathogens
}

Stefan Schwarz, Alexander Böttner, H. Mohamed Hafez, Luc Goosens, Katrin Hartmann, Martin Kaske, Corinna Kehrenberg, Manfred Kietzmann, Dieter Klarmann, Günter Klein, et al.

\section{To cite this version:}

Stefan Schwarz, Alexander Böttner, H. Mohamed Hafez, Luc Goosens, Katrin Hartmann, et al.. A proposal of clinical breakpoints for amoxicillin applicable to porcine respiratory tract pathogens. Veterinary Microbiology, 2007, 126 (1-3), pp.178. 10.1016/j.vetmic.2007.06.023 . hal-00532287

\section{HAL Id: hal-00532287 https://hal.science/hal-00532287}

Submitted on 4 Nov 2010

HAL is a multi-disciplinary open access archive for the deposit and dissemination of scientific research documents, whether they are published or not. The documents may come from teaching and research institutions in France or abroad, or from public or private research centers.
L'archive ouverte pluridisciplinaire HAL, est destinée au dépôt et à la diffusion de documents scientifiques de niveau recherche, publiés ou non, émanant des établissements d'enseignement et de recherche français ou étrangers, des laboratoires publics ou privés. 


\section{Accepted Manuscript}

Title: A proposal of clinical breakpoints for amoxicillin applicable to porcine respiratory tract pathogens

Authors: Stefan Schwarz, Alexander Böttner, H. Mohamed Hafez, Luc Goosens, Katrin Hartmann, Martin Kaske, Corinna Kehrenberg, Manfred Kietzmann, Dieter Klarmann,

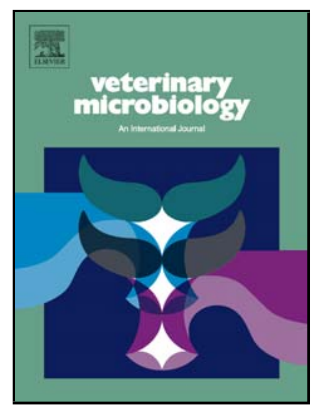
Günter Klein, Peter Krabisch, Gabriele Luhofer, Angelika

Richter, Bianka Schulz, Claudia Sigge, Karl-Heinz

Waldmann, Jürgen Wallmann, Christiane Werckenthin

PII:

S0378-1135(07)00323-9

DOI: doi:10.1016/j.vetmic.2007.06.023

Reference: VETMIC 3746

To appear in:

VETMIC

Received date:

$20-4-2007$

Revised date: $10-5-2007$

Accepted date: 4-6-2007

Please cite this article as: Schwarz, S., Böttner, A., Hafez, H.M., Goosens, L., Hartmann, K., Kaske, M., Kehrenberg, C., Kietzmann, M., Klarmann, D., Klein, G., Krabisch, P., Luhofer, G., Richter, A., Schulz, B., Sigge, C., Waldmann, K.-H., Wallmann, J., Werckenthin, C., A proposal of clinical breakpoints for amoxicillin applicable to porcine respiratory tract pathogens, Veterinary Microbiology (2007), doi:10.1016/j.vetmic.2007.06.023

This is a PDF file of an unedited manuscript that has been accepted for publication. As a service to our customers we are providing this early version of the manuscript. The manuscript will undergo copyediting, typesetting, and review of the resulting proof before it is published in its final form. Please note that during the production process errors may be discovered which could affect the content, and all legal disclaimers that apply to the journal pertain. 


\section{A proposal of clinical breakpoints for amoxicillin applicable to} porcine respiratory tract pathogens

a Institut für Tierzucht, Bundesforschungsanstalt für Landwirtschaft (FAL), Neustadt-Mariensee,

${ }^{b}$ Intervet Innovation $\mathrm{GmbH}$, Schwabenheim, ${ }^{c}$ Institut für Geflügelkrankheiten, Freie Universität Berlin,

${ }^{d}$ Pfizer $\mathrm{GmbH}$, Karlsruhe,

${ }^{e}$ Medizinische Kleintierklinik, Ludwig-Maximilians-Universität München,

${ }^{f}$ Institut für Physiologie, Wissenschaftszentrum Weihenstephan, Freising-Weihenstephan,

${ }^{9}$ Institut für Pharmakologie, Toxikologie and Pharmazie, Tierärztliche Hochschule Hannover,

${ }^{\mathrm{h}}$ Veterinärinstitut Oldenburg, LAVES,

' Institut für Lebensmittelqualität and -sicherheit, Tierärztliche Hochschule Hannover,

j TGD Bayern, Poing,

${ }^{k}$ Landesuntersuchungsamt Rheinland-Pfalz, Institut für Lebensmittel tierischer Herkunft, Koblenz,

' Institut für Pharmakologie and Toxikologie, Freie Universität Berlin,

${ }^{m}$ Bundesverband für Tiergesundheit (BfT), Bonn,

${ }^{n}$ Klinik für kleine Klauentiere, Tierärztliche Hochschule Hannover,

${ }^{\circ}$ Bundesamt für Verbraucherschutz and Lebensmittelsicherheit (BVL), Berlin,

${ }^{\mathrm{p}}$ Institut für Medizinische Mikrobiologie, Infektions- and Seuchenmedizin, Ludwig-Maximilians-

Universität München.

short title: clinical breakpoints for amoxicillin 
* Corresponding author. Tel: +49-5034-871-241, Fax: +49-5034-871-246.

34

E-mail address: stefan.schwarz@fal.de (S. Schwarz) 


\section{Abstract}

In the present position paper, an attempt was made to establish clinical breakpoints of amoxicillin to classify porcine respiratory tract pathogens as susceptible, intermediate or resistant based on their minimum inhibitory concentrations of amoxicillin. For this, a thorough review of the published literature with regard to swine-specific pharmacological data (including dosages of amoxicillin applied and routes of administration used), clinical efficacy, and in vitro susceptibility of the target pathogens was performed. Based on the comparative analysis of the results, the working group "Antibiotic Resistance" of the German Society for Veterinary Medicine (DVG) proposed to classify porcine respiratory tract pathogens that show MIC values of amoxicillin of $\leq 0.5 \mu \mathrm{g} / \mathrm{ml}$ as "susceptible", those with MICs of $1 \mu \mathrm{g} / \mathrm{ml}$ as "intermediate", and those with MICs of $\geq 2 \mu \mathrm{g} / \mathrm{ml}$ as "resistant".

\section{Key words: antibiotic therapy, breakpoints, swine, respiratory diseases, amoxicillin}




\section{Introduction}

According to prudent use guidelines, the in-vitro susceptibility of bacteria against antimicrobial agents of bacteria, which are considered to be causative for a specific disease condition, should be determined prior to therapy. This approach shall ensure that only those substances are applied to which the causative bacterial pathogens exhibit susceptibility under in-vitro conditions and, therefore, are likely to result in a successful treatment. The classification of the tested bacteria as either "susceptible", "intermediate", or "resistant" is based on breakpoints. Currently, two distinct groups of breakpoints are used: microbiological breakpoints (also referred to as epidemiological cut-off values) and clinical breakpoints (Bywater et al., 2006). Microbiological breakpoints differentiate between subpopulations which exhibit different levels of susceptibility to a specific antimicrobial agent. In bimodal distributions of MIC values, the microbiological breakpoints separate a presumably susceptible subpopulation from a presumably resistant subpopulation (Bywater et al., 2006). However, microbiological breakpoints do not consider pharmacological aspects of the antimicrobial agents administered. In contrast, the concentration of the antimicrobial agents which can be achieved by the recommended dosing at the site of infection is a key parameter for the determination of clinical breakpoints (Bywater et al., 2006). Other aspects relevant for the determination of clinical breakpoints are the minimum inhibitory concentration of the causative pathogens as well as pharmacokinetic and toxicological aspects. The complexity of parameters involved in the determination of clinical breakpoints shows that clinical breakpoints do not represent values that can be directly measured. Instead, they have to be derived from the results of extensive studies which take into account 
microbiological, pharmacological and clinical aspects (Böttner et al., 2000). This has previously been shown in detail for the establishment of clinical breakpoints for tilmicosin (Shryock et al., 1996) and ceftiofur (Burton et al., 1996).

Approved clinical breakpoints are an important criterion in the decision for or against a specific antimicrobial agent in therapeutic interventions (Woolcock, 1993; DIN, 1992; NCCLS, 2002b). However, it should be noted that clinical breakpoints do not guarantee in every case that the treatment will be successful, but they help to minimize the risk of therapy failures (Richter et al., 2006). While clinical breakpoints are in principle established for an antimicrobial agent, they initially apply only to the original pharmaceutical product used and are not necessarily valid for the respective generic substances.

Due to the lack of veterinary-specific data, the classification of veterinary pathogens as susceptible or resistant is often based on breakpoints adopted from human medicine (NCCLS, 2002a; 2004). This applies particularly to older antibiotics that have been in veterinary use for several decades, such as tetracyclines, ampicillin, or amoxicillin. Since the spectrum of bacterial pathogens as well as the distribution and metabolism of antimicrobial agents differ distinctly in humans and animals, the nonverified adoption of breakpoints from human medicine for use in veterinary medicine is scientifically questionable.

This position paper represents an attempt to establish veterinary-specific clinical breakpoints for amoxicillin based on data available in the published literature. Amoxicillin is a member of the semi-synthetic aminopenicillin group of antibiotics which exhibit a broad spectrum of activity against Gram-positive and Gram-negative bacteria and displays a bactericidal mode of action. Amoxicillin is used extensively in the treatment of 
bacterial infections of animals and is approved in a variety of formulations for use in cattle, pigs, poultry, horses, dogs and cats. For pigs, aqueous and oily preparations for parenteral administration (intravenous, subcutaneous, and intramuscular) are worldwide approved. Water-soluble powders are also available for oral medication either via feed or drinking water. Our attempt to deduce a clinical breakpoint for amoxicillin which shall be applicable to porcine respiratory tract pathogens is based on known data of the pharmacokinetics of amoxicillin in swine, the results of clinical efficacy studies, and available data on the in-vitro susceptibility of pathogens causing porcine respiratory tract infections, such as Actinobacillus pleuropneumoniae, Pasteurella multocida, Streptococcus suis, Bordetella bronchiseptica, and Haemophilus parasuis.

\section{Pharmacokinetics of amoxicillin in the pig}

There are several studies which investigated the pharmacokinetic parameters of amoxicillin in pigs. However, all these studies varied in either the dosages used, the route of administration of amoxicillin, the health status of the animals, or other parameters. Moreover, not all the studies listed determined the same parameters by the same methodology. This situation makes it difficult to compare the results obtained in the different studies.

\subsection{Key studies}

A comparative overview of the pharmacokinetics of amoxicillin in the pig after parenteral and oral administration is presented in Tables 1a-b. The pharmacokinetic 
parameters of amoxicillin in various formulations and dosages was studied systematically by Agerso and Friis (1998a). To determine its bioavailability, amoxicillin was administered in different formulations to separate groups of healthy pigs by intramuscular (i.m.) or oral (p.o.) route in comparison with intravenous (i.v.) administration. For the i.v. administration, the sodium salt of amoxicillin was used at a dosage of $8.6 \mathrm{mg} / \mathrm{kg}$ body weight. An amoxicillin suspension (trihydrate salt) was administered in the conventional formulation (Clamoxyl ${ }^{\circledR}$ ) and in the long-acting formulation (Clamoxyl LA $®$ ) at a dosage of $14.7 \mathrm{mg} / \mathrm{kg}$ i.m., respectively. A watersoluble amoxicillin preparation (Clamoxyl Soluble Powder $®$ ) was administered to the pigs (bodyweight $30-50 \mathrm{~kg}$ ) by gavage, once on an empty stomach (trial 1) and once just before feeding (trial 2), at a dosage of $10.1 \mathrm{mg} / \mathrm{kg}$ p.o..

After i.v. administration, the active substance was excreted rapidly. The mean residence time (MRT) in the serum was $1.2-1.5 \mathrm{~h}$ and the volume of distribution at steady-state $\left(\mathrm{V}_{\mathrm{ss}}\right)$ was $0.63-0.55 \mathrm{l} / \mathrm{kg}$. The area under the curve $(\mathrm{AUC})$ values and the elimination half-life ( $\mathrm{t}_{1 / 2} 1.8 \pm 0.3 \mathrm{~h}$ vs. $3.6 \pm 0.4 \mathrm{~h}$ ) differed significantly after i.v. injections in the two experiments described by Agerso and Friis (1998a; see Table 1). Studies done by Martinez-Larranaga et al. (2004) with i.v. administration of $20 \mathrm{mg} / \mathrm{kg}$ amoxicillin revealed different results as compared to those of Agerso and Friis (1998a). In particular, the AUC, MRT and the $\mathrm{V}_{\mathrm{ss}}$ differed (Table 1).

After i.m. administration of the conventional oily suspension, the active substance reached its maximum serum concentration $\left(C_{\max }\right)$ of $5.1 \mu \mathrm{g} / \mathrm{ml}$ after $2 \mathrm{~h}$. The MRT was $8.8 \mathrm{~h}$ and the bioavailability $83 \%$ (Agerso and Friis, 1998a; Table 1). The long-acting formulation of amoxicillin was absorbed more slowly from the injection site, which is reflected by the longer MRT and by the lower $C_{\max }$. The first concentration peak of 1.7 
$\mu \mathrm{g} / \mathrm{ml}$ was reached after $1.3 \mathrm{~h}$ and the second peak of $0.8 \mu \mathrm{g} / \mathrm{ml}$, after $6.6 \mathrm{~h}$. The calculated bioavailability after i.m. injections was $83 \%$ or in the case of the long acting form 126\% (Agerso and Friis, 1998a).

Absorption of amoxicillin after oral administration was slower and incomplete, especially in fed pigs (Table 2), as shown by trial 2 in the studies of Agerso and Friis (1998a). The $C_{\max }$ value of $1.6 \mu \mathrm{g} / \mathrm{ml}$ was seen after $1.9 \mathrm{~h}$ in fasted pigs (trial 1 ), while a lower peak concentration of $0.8 \mu \mathrm{g} / \mathrm{ml}$ was reached after $3.6 \mathrm{~h}$ in fed pigs (Agerso and Friis, 1998a). Oral bioavailability was only $31 \%$ in fasted animals and $28 \%$ in fed animals. However, the observed differences in bioavailability, the $\mathrm{C}_{\max }$ and the time to maximum serum concentration $\left(t_{\max }\right)$ were not statistically significant. Agerso et al. (1998) conducted further studies in a herd of 201 pigs. The animals received amoxicillin at a dosage of $23 \mathrm{mg} / \mathrm{kg}$ on 5 consecutive days via drinking water. The concentration of amoxicillin in the blood serum was measured in 10 randomly selected pigs and varied between $0.5 \mu \mathrm{g} / \mathrm{ml}$ and of $1.3 \mu \mathrm{g} / \mathrm{ml}$.

\subsection{Other studies}

Agerso and Friis (1998b) also conducted studies on the concentration and distribution of amoxicillin in tissues of healthy pigs. The peak concentration following i.v. administration of amoxicillin at $8.6 \mathrm{mg} / \mathrm{kg}$ was reached after $1 \mathrm{~h}$ in the lungs (mucosa: $3.02 \mu \mathrm{g} / \mathrm{ml}$, tissue: $2.97 \mu \mathrm{g} / \mathrm{ml}$, and bronchial secretion: $2.1 \mu \mathrm{g} / \mathrm{ml})$. Clearance $(\mathrm{Cl})$ of amoxicillin from the lungs occurred much slower than from the plasma. The results were confirmed in a further study in pigs suffering from an infection with $A$. pleuropneumoniae (Agerso and Friis, 1998c). The pharmacokinetic parameters did not differ significantly between healthy and diseased animals after a single i.v. dose of $8.6 \mathrm{mg} / \mathrm{kg}$ amoxicillin. 
However, the concentrations of the active substance were slightly higher in bronchial secretions $(2.29 \mu \mathrm{g} / \mathrm{ml})$ of acutely diseased animals and lower in pneumonic lung tissue $(1.70 \mu \mathrm{g} / \mathrm{ml})$. The $\mathrm{C}_{\max }$ was reached after $2 \mathrm{~h}$. The coefficient of distribution, measured from the AUC between tissue and plasma, was 0.53 for bronchial secretion and 0.44 for both diseased and healthy lung tissue.

Sumano et al. (2004) described the bioavailability of three different amoxicillin premix formulations in a comparative study which differed in the coating of the active ingredient amoxicillin to protect it from degradation during feed manufacture and storage conditions. The premixes were administered orally by gavage mixed to feed with gelatine in order to achieve a dose of $20 \mathrm{mg} / \mathrm{kg}$ body weight. As indicated by the higher AUC, the oral bioavailability of a special amoxicillin formulation, produced by a coating procedure, was significantly higher when compared with two conventional amoxicillin products. The $t_{\max }$ values corresponded well with the results of Agerso and Friis (1998a). However, Sumano et al. (2004) found significant differences between the formulations in the AUC and in the $C_{\max }$ values. Interestingly, the $C_{\max }$ values and the AUC of the conventional formulations were comparable to the results of Agerso and Friis (1998a) although the administered dose was twice as high at $20 \mathrm{mg} / \mathrm{kg}$. The effect of the formulation on the oral bioavailability of amoxicillin was also described by Anfossi et al. (2002), showing that the relative bioavailability can be increased by up to $50 \%$ with specific amoxicillin formulations.

Martinez-Larranga et al. (2004) studied the pharmacokinetic parameters of amoxicillin after single i.v. and oral doses of $20 \mathrm{mg} / \mathrm{kg}$ bw administered at five consecutive days in a cross-over trial in pigs of approximately $80 \mathrm{~kg}$ body weight. The $\mathrm{C}_{\max }$ values measured in serum after oral administration were distinctly higher than in 
the studies of Agerso and Friis (1998a, 1998b) and Sumano et al. (2004), namely 7.4 $\mu \mathrm{g} / \mathrm{ml}$ compared with $0.8 \mu \mathrm{g} / \mathrm{ml}$ and $1.6 \mu \mathrm{g} / \mathrm{ml}$, respectively. Oral bioavailability of $41 \%$ was also considerably higher than the values of $28 \%-31 \%$ recorded by Agerso and Friis (1998a, b) (Table 3).

Anadon et al. (2000) determined the pharmacokinetic parameters of amoxicillin after a single oral medication of fasting pigs at a dosage of $20 \mathrm{mg} / \mathrm{kg}$. Therapeutically relevant serum levels $(>0.3 \mu \mathrm{g} / \mathrm{ml})$ were reached after ca. $30 \mathrm{~min}$ and persisted for up to $12 \mathrm{~h}$ after administration of the drug. The pharmacokinetic parameters were comparable to those measured by Martinez-Larranga et al. (2004).

Hernandes et al. (2005) determined the bioavailability of an oral amoxicillin formulation after a single medication at $15 \mathrm{mg} / \mathrm{kg}$. Compared with i.v. injections, the oral bioavailability was merely $11 \%$, hence considerably lower than in the studies by Agerso and Friis (1998a, b), Anadon et al. (2000), and Martinez-Larranga et al. (2004).

Morthorst (2002) described the oral bioavailability of amoxicillin in weaned piglets after oral administration under different experimental conditions. A dose of $20 \mathrm{mg} / \mathrm{kg}$ amoxicillin incorporated into the daily ratio of feed or drinking water resulted in very low levels in the serum. The bioavailability ranged from $6 \%$ to $29 \%$. However, after a single oral dose administered in $200 \mathrm{ml}$ drinking water directly into the stomach (intragastrical application) in fastened pigs, Morthorst (2002) found much higher and more variable values for $C_{\max }(21.55 \mu \mathrm{g} / \mathrm{ml} \pm 34.55)$, a bioavailability of $91 \%$, and a short $t_{\max }$ of about 30 minutes (Table 3). These data indicate that the oral bioavailability of amoxicillin can be considerably reduced by interactions with feed.

The plasma protein binding rate of amoxicillin in pigs has been described to be 28\% (Villa et al., 1994). This is in agreement with the findings of Agerso and Friis 
223 (1998b) which measured $24 \pm 9 \%$ in plasma and $21 \pm 13 \%$ in bronchial secretions.

Protein binding measured in pigs experimentally infected with $A$. pleuropneumoniae (Agerso and Friis, 1998c) were slightly lower (plasma: $17 \pm 8 \%$, bronchial secretions: 13 $\pm 6 \%$ in bronchial secretions). The data suggest that there is good availability of the drug in the infected tissue.

\section{Susceptibility of amoxicillin among bacteria associated with} porcine respiratory infections

The major bacterial pathogens involved in porcine respiratory tract infections are $A$. pleuropneumoniae, P. multocida, H. parasuis, B. bronchiseptica, S. suis, and Mycoplasma hyopneumoniae. While there is currently no guideline available for the reliable performance of in-vitro susceptibility testing of mycoplasmas, the CLSI guideline M31-A2 (NCCLS, 2002a) describes in detail how to perform the susceptibility testing of some of the other porcine respiratory tract pathogens, e.g. P. multocida, $A$. pleuropneumoniae or Streptococcus spp.. Susceptibility testing of B. bronchiseptica and H. parasuis used CLSI methods as laid down in document M31-A2 with either cationsupplemented Mueller-Hinton broth (B. bronchiseptica) or veterinary fastidious medium (H. parasuis) as the test medium.

The studies conducted by the Federal Office of Consumer Protection and Food Safety (Bundesamt für Verbraucherschutz and Lebensmittelsicherheit, BVL) as part of the GERM-Vet national resistance monitoring program in Germany provide a reliable database on the current resistance status of selected veterinary pathogenic bacteria 
(Wallmann et al., 2003). The GERM-Vet program follows the CLSI guidelines and determines MIC values by broth microdilution. According to the CLSI guidelines M31-A2 and M31-S1, ampicillin is considered as the class representative of the aminobenzylpenicillins, of which ampicillin and amoxicillin are approved for veterinary use. As a consequence, ampicillin is commonly used to test for susceptibility to amoxicillin since the results obtained with ampicillin are also valid for amoxicillin (NCCLS 2002a; 2004). Thus, in most of the studies mentioned below the isolates were tested for susceptibility against ampicillin while amoxicillin was used only in a few studies (Marie et al., 2002; Gutiérrez-Martín et al., 2006; Vela et al., 2005).

Among the porcine respiratory tract pathogens, susceptibility data of $P$. multocida (Wallmann et al., 2003, 2004) and B. bronchiseptica for ampicillin (Wallmann et al., 2004; Kadlec et al., 2004) have been published so far. The in-vitro susceptibility of $P$. multocida proved to be rather stable for isolates obtained during the years 2001, 2002/2003, and 2004/2005 in Germany (Table 4). Similar MIC values have also been reported for $P$. multocida isolates from Spain collected during 1987/1988 and 2003/2004 (Yanedt et al., 2006). Most of the P. multocida isolates exhibited low MIC values in the range of $\leq 0.25 \mu \mathrm{g} / \mathrm{ml}$, independently of their geographical origin. In contrast, $B$. bronchiseptica isolates exhibited high $\mathrm{MIC}_{50}$ and $\mathrm{MIC}_{90}$ values of ampicillin ranging between 8-16 $\mu \mathrm{g} / \mathrm{ml}$ and $16-32 \mu \mathrm{g} / \mathrm{ml}$, respectively (Table 4).

There are only few recently published data available for $A$. pleuropneumoniae (Matter et al., 2007; Gutiérrez-Martín et al., 2006), S. suis (Wisselink et al., 2006; Vela et al., 2005; Marie et al., 2002), and H. parasuis (Aarestrup et al., 2004; Martín de la Fuente et al., 2007). These studies, all following CLSI methodology, showed that $A$. pleuropneumoniae (Gutiérrez-Martín et al., 2006) and H. parasuis (Martín de la Fuente 
et al., 2007) from Spain showed distinctly higher MICs for the aminopenicillins tested than isolates from Switzerland (Matter et al., 2007) and Germany or Denmark (Aarestrup et al., 2004) and UK (Martín de la Fuente et al., 2007), respectively (Table 4). In the recent GERM-Vet studies conducted by the BVL for the years 2004 and 2005 on $124 A$. pleuropneumoniae isolates, the $\mathrm{MIC}_{50}$ and $\mathrm{MIC}_{90}$ values of ampicillin were $0.25 \mu \mathrm{g} / \mathrm{ml}$. For S. suis, $\mathrm{MIC}_{50}$ and $\mathrm{MIC}_{90}$ values of ampicillin for the years 2004 and 2005 - as determined in the GERM-Vet program - were $\leq 0.03$ and $0.06 \mu \mathrm{g} / \mathrm{ml}$, respectively (Table 4). This is also in agreement with data from Spain (Vela et al., 2005) and confirms the usual susceptibility of streptococci to penicillins. Other studies on the antimicrobial susceptibility of S. suis did not provide a distribution of MICs of amoxicillin (Marie et al., 2002), or tested only penicillin as the sole representative of the class of penicillins (Wisselink et al., 2006).

\section{Clinical efficacy of amoxicillin in respiratory infections}

The efficacy of amoxicillin in diseases caused by $A$. pleuropneumoniae was confirmed in an experimental infection model and in clinical field studies. Tanigawa and Sawada (2003) investigated the pharmacodynamic effect of subinhibitory and inhibitory amoxicillin concentrations in-vitro and in-vivo using a long-acting amoxicillin formulation in pigs experimentally infected with a strain of $A$. pleuropneumoniae which exhibited an MIC of $0.39 \mu \mathrm{g} / \mathrm{ml}$. The animals of group I, which were treated with a dose of $7.5 \mathrm{mg} / \mathrm{kg}$ i.m., had a slower clinical recovery than the pigs treated with a higher dose of $15 \mathrm{mg} / \mathrm{kg}$ i.m.. The comparative kinetics of the administered doses in relation to the MIC of 0.39 
$\mu \mathrm{g} / \mathrm{ml}$ for the $A$. pleuropneumoniae strain suggested almost entirely subinhibitory pulmonary concentrations in group I, which explained the slower clinical recovery measured by the clinical score and the higher lung lesion score. In contrast, in group II (15 mg/kg amoxicillin i.m.) concentrations above the MIC could be expected throughout the treatment period.

In another experiment, Tanigawa and Sawada (2002) studied the effect of a longacting formulation of amoxicillin in pigs. The animals were treated with amoxicillin (15 $\mathrm{mg} / \mathrm{kg}$ i.m.) $22 \mathrm{~h}$ before the experimental infection with A. pleuropneumoniae. In view of the pharmacokinetic data (Tanigawa and Sawada, 2002; Table 1b), the MIC (0.39 $\mu \mathrm{g} / \mathrm{ml}$ ) was probably not reached over the whole period of time of the infection, but the authors reported that only a few animals became ill.

Further studies, also in A. pleuropneumoniae-infected pigs, were conducted by Roy et al. (2000a, 2000b). Amoxicillin (Suramox ® 50) was administered orally at a dosage of $20 \mathrm{mg} / \mathrm{kg} / \mathrm{day}$ on five consecutive days, either via feed or drinking water. The clinical efficacy of amoxicillin was demonstrated versus an untreated control group by significant reduction of clinical signs, by the absence of gross pathological changes and also by microbiological criteria. No information was provided concerning the susceptibility of the A. pleuropneumoniae isolates used.

Thomas et al. (2000) reported results from a clinical field trial with amoxicillin trihydrate (without aluminium stearate, Clamoxyl $®$ ) in comparison to marbofloxacin. The study was conducted on pig holdings in France, Germany and the Netherlands. The clinical efficacy of amoxicillin at a dose of $7 \mathrm{mg} / \mathrm{kg}$ after i.m. administration for 3-5 consecutive days was $68 \%$ in comparison to $74.5 \%$ for the animals treated with marbofloxacin $(7 \mathrm{mg} / \mathrm{kg})$. No statistically significant differences were found. The typical 
pathogens implicated in porcine respiratory disease, A. pleuropneumoniae, S. suis, $P$. multocida, and $M$. hyopneumoniae, were isolated, but there were no data on the susceptibility of these infectious agents to amoxicillin and no information about untreated controls.

\section{Clinical breakpoints for amoxicillin}

Most breakpoints for antimicrobial agents considered in veterinary medicine are derived from human medicine. The few internationally approved veterinary-specific clinical breakpoints established to date have been published in the CLSI documents M31-A2 (2002a) and M31-S1 (2004). No veterinary-specific breakpoints are available for ampicillin or amoxicillin in these two documents. When summarizing the data available for amoxicillin with regard to the pharmacodynamics, pharmacokinetics, clinical efficacy and in vitro susceptibility of the target pathogens, the following aspects must be taken into consideration.

From the pharmacodynamic point of view, amoxicillin belongs to a class of timedependent antibiotics. This means that its concentration in the infected tissue must be above the MIC of the causative bacterial pathogen (Craig, 1998; Kietzmann et al., 2004). The time for which the antibiotic concentration must be above the MIC is determined by various factors, but it should not be less than $30-40 \%$ of the dosing interval (Craig, 1998).

The pharmacokinetics of amoxicillin in pigs have been adequately described in the literature. It can be assumed that the serum concentration is equivalent to the 
concentration in the interstitial fluid, where most infectious agents reside (Craig, 1995). The tissue concentration of amoxicillin is therefore not necessarily the decisive parameter since the actual concentration of the antibiotic at the site of infection might be underestimated. According to studies by Agerso and Friis (1998a, b, c), the ratio of AUC tissue to AUC serum for bronchial secretion of sick animals is about 0.55 . However, this does not permit the derivation of a concentration curve in bronchial secretion. Instead, the serum pharmacokinetics of the drug should be used as the basis for estimating the concentration in tissue, as suggested by Craig (1995). The predicted tissue concentration in the lungs following parenteral administration (i.v. or i.m.) of amoxicillin at a dosage of $7.5-15 \mathrm{mg} / \mathrm{kg}$ amounts to $0.5-1.0 \mu \mathrm{g} / \mathrm{ml}$ for about $6-12 \mathrm{~h}$, depending on the formulation. This estimation is mainly based on the data described by Agerso and Friis (1998b) together with the available data on the plasma half-life time and the AUC values (Table 1b). Orally administered products have to be considered separately because of their different bioavailability and the different pharmaceutical formulations. In order to reach therapeutically relevant serum levels in plasma of $0.5-1.0 \mu \mathrm{g} / \mathrm{ml}$, doses of at least $10 \mathrm{mg} / \mathrm{kg}$ twice daily are required (Agerso and Friis, 1998a, b; Agerso et al., 1998).

Only few data are available on the clinical efficacy of amoxicillin (Clamoxyl囚) in pigs (Thomas et al., 2000; Tanigawa and Sawada, 2003). Thomas et al. (2000) reported the efficacy of the amoxicillin-containing product as being similar to that of marbofloxacin $\left(\right.$ Marbocyl $^{\circledR}$ ), but there is no information about the susceptibility of the infecting pathogens. In infection experiments done by Tanigawa and Sawada (2003), the susceptibility of $A$. pleuropneumoniae to amoxicillin, expressed as its MIC, was determined at $0.39 \mu \mathrm{g} / \mathrm{ml}$. A long-acting formulation of amoxicillin produced a clinical 
cure at dose rates of $7.5 \mathrm{mg} / \mathrm{kg}$ and $15 \mathrm{mg} / \mathrm{kg}$ i.m., but this result was achieved earlier in the group of animals given the high dose. Although it appears to be unlikely for the treatment with the lower dose, the infectious agent was not longer isolated from these animals, indicating a complete elimination of the pathogens. Therefore, it can be assumed that bacteria with an MIC of approximately $0.4 \mu \mathrm{g} / \mathrm{ml}$ are reliably killed and completely eliminated from the lungs. This confirms the assumption that clinical efficacy corresponds with consistent concentrations of the active ingredient in the lungs of approx. $0.5-1 \mu \mathrm{g} / \mathrm{ml}$.

The susceptibility status of field isolates of porcine $P$. multocida isolated in Germany (Wallmann et al., 2003; 2004) revealed that the vast majority of the strains exhibited MICs of $\leq 0.5 \mu \mathrm{g} / \mathrm{ml}$, suggesting that $P$. multocida-based infections in pigs can be treated reliably and efficiently with amoxicillin. The same applies - with few exceptions (Table 4) - to infections with the bacteria A. pleuropneumoniae, H. parasuis, and S. suis. The distribution of MIC values against $B$. bronchiseptica was also highly homogeneous with the $\mathrm{MIC}_{50}$ and $\mathrm{MIC}_{90}$ values of $8-16 \mu \mathrm{g} / \mathrm{ml}$ (Wallmann et al., 2004; Kadlec et al., 2004). However, an amoxicillin concentration which is able to inhibit the growth of $B$. bronchiseptica cannot be reached - neither in serum nor in tissue - with the approved products at the recommended dosage. Thus, amoxicillin should not be taken into consideration for therapeutic interventions against $B$. bronchiseptica infections. It is also noteworthy that Mycoplasma hyopneumoniae and other Mycoplasma spp. lack the target structure of amoxicillin, namely the cell wall. As a consequence, amoxicillin - as all other antimicrobial agents that act on the cell wall synthesis - is inactive against mycoplasmas and therefore should not be used to treat infections caused by Mycoplasma spp.. 
Based on all aforementioned pharmacological, clinical and microbiological parameters, we suggest the following clinical breakpoints for amoxicillin to be used for the classification of bacterial pathogens involved in porcine respiratory tract infections: $\leq 0.5 \mu \mathrm{g} / \mathrm{ml}$ for "susceptible", $1.0 \mu \mathrm{g} / \mathrm{ml}$ for "intermediate", and $\geq 2 \mu \mathrm{g} / \mathrm{ml}$ for "resistant". This recommendation takes into account the diversity and completeness of the available data with regard to the formulations, dosages and treatment intervals used. Mainly in view of the great paucity of clinical test results, the recommended breakpoint for the classification "susceptible" has been set at the lower end of the possible range between $0.5 \mu \mathrm{g} / \mathrm{ml}$ and $1 \mu \mathrm{g} / \mathrm{ml}$.

\section{References}

Aarestrup, F.M., Seyfarth, A.M., Angen, Ø., 2004. Antimicrobial susceptibility of Haemophilus parasuis and Histophilus somni from pigs and cattle in Denmark. Vet. Microbiol. 101, 143-146.

Agerso, H., Friis, C., 1998a. Bioavailability of amoxicillin in pigs. J. Vet. Pharmacol. Ther. 21, 41-46.

Agerso, H., Friis, C., 1998b. Penetration of amoxicillin into the respiratory tract tissues and secretions in pigs. Res. Vet. Sci. 64, 245-250.

Agerso, H., Friis, C., 1998c. Penetration of amoxicillin to the respiratory tract tissues and secretions in Actinobacillus pleuropneumoniae infected pigs. Res. Vet. Sci. 64, 251257. 
Agerso, H., Friis, C., Haugegaard, J., 1998. Water medication of a swine herd with amoxicillin. J. Vet. Pharmacol. Ther. 21, 199-202.

Anadon, A., Martinez-Larranaga, M.R., Diaz, M.J., Martinez, M.A., Martinez, M., Frejo, M.T., Tafur, M., Bringas, P., 2000. Pharmacokinetic and oral bioavailability of amoxicillin in pigs. In: Proceedings of the 8th International Congress of the European Association for Veterinary Pharmacology and Toxicology (EAVPT), 66, Jerusalem, p. 86

Anfossi, P., Zaghini, A., Grassigli, G., Menotta, S., Fedrizzi, G., 2002. Relative oral bioavailability of microgranulated amoxicillin in pigs. J. Vet. Pharmacol. Ther. 25, 329-334.

Böttner, A., de Jong, A., Schmid, P., Schüller, S., Traeder, W. , Weiskopf, S., 2000. Determination of breakpoints for veterinary medically relevant antibiotics for resistance assessment of veterinary pathogens [in German, with English abstract]. Berl. Münch. Tierärztl. Wschr. 113, 344-347.

Burton, P.J., Thornberry, C., Yee, Y.C., Watts, J.L., Yancey Jr., R.J., 1996. Interpretive criteria for antimicrobial susceptibility testing of ceftiofur against bacteria associated with swine respiratory disease. J. Vet. Diagn. Invest. 8, 464-468.

Bywater, R., Silley, P., Simjee, S., 2006. Antimicrobial breakpoints - definitions and conflicting requirements. Vet Microbiol. 118:158-159.

Craig, W.A., 1995. Interrelationship between pharmacokinetics and pharmacodynamics in determining dosage regimens for broad-spectrum cephalopsorins. Diagn. Microbiol. Infect. Dis., 22, 89-96.

Craig, W.A., 1998. Pharamcokinetic/pharmacodynamic parameters: Rationale for antibacterial dosing of mice and men. Clin. Infect. Dis. 26, 1-12. 
Deutsches Institut für Normung e.V. (Hrsg.): Medizinische Mikrobiologie und Immunologie: diagnostische Verfahren (2000): 3. Auflage, DIN-Taschenbücher, Band 222, 151-294.

Gutiérrez-Martín, C.B., Garciá del Blanco, N., Blanco, M., Navas, J., Rodríguez-Ferri, E.F., 2006. Changes in antimicrobial susceptibility of Actinobacillus pleuropneumoniae isolated from pigs in Spain during the last decade. Vet. Microbiol. $115,218-222$.

Hernandez, E., Rey, R., Puig, M., Garcia, M.A., Solans, C., Bregante M.A., 2005. Pharmacokinetics and residues of a new oral amoxicillin formulation in piglets: a preliminary study. Vet. J. 170, 237-242.

Kadlec, K., Kehrenberg, C., Wallmann, J., Schwarz, S., 2004. Antimicrobial susceptibility of Bordetella bronchiseptica isolates from porcine respiratory tract infections. Antimicrob. Agents Chemother. 48, 4903-4906.

Kietzmann, M., Böttner, A., Hafez, H.M., Kehrenberg, C., Klarmann, D., Krabisch, P., Kühn, T., Luhofer, G., Richter, A., Schwarz, S., Traeder, W., Waldmann, K.-H., Wallmann, J., Werckenthin, C., 2004. Antimicrobial susceptibility testing of bacteria isolated from animals: considerations concerning the predefinition of breakpoints from the clinical pharmacological viewpoint [in German, with English abstract]. Berl. Münch. Tierärztl. Wschr. 117, 81-87.

Marie, J., Morvan, H., Berthelot-Hérault, F., Sanders, P., Kempf, I., Gautier-Bouchardon, A.V., Jouy, E., Kobisch, M., 2002. Antimicrobial susceptibility of Streptococcus suis isolated from swine in France and from humans in different countries between 1996 and 2000. J. Antimicrob. Chemother. 50, 201-209. 
Martín de la Fuente, A.J., Tucker, A.W., Navas, J., Blanco, M., Morris, S.J., GutiérrezMartín, C.B., 2007. Antimicrobial susceptibility patterns of Haemophilus parasuis from pigs in the United Kingdom and Spain. Vet. Microbiol. 120, 184-191.

Martinez-Larranaga, M.R., Anadon, A., Martinez, M.A., Diaz, M.J., Frejo, M.T., Castellano, V.J., Isea, G., de la Cruz, C.O., 2004. Pharmacokinetics of amoxicillin and the rate of depletion of its residues in pigs. Vet. Rec. 154, 627-632.

Matter, D., Rossano, A., Limat, S., Vorlet-Fawer, L., Brodard, I., Perreten, V., 2007. Antimicrobial resistance profile of Actinobacillus pleuropneumoniae and Actinobacillus porcitonsillaris. Vet. Microbiol. (doi: 10.1016/j.vetmic.2007.01.009)

Morthorst, D., 2002. Bioavailability of amoxicillin in weaning piglets after oral and parenteral administration by feed and water under different conditions [in German, with English abstract]. Inaugural-Dissertation, Tierärztliche Hochschule Hannover.

National Committee for Clinical Laboratory Standards (NCCLS), 2002a. Performance standards for antimicrobial disk and dilution susceptibility test for bacteria isolated from animals - Second edition: Approved standard M31-A2. NCCLS, Wayne, PA, USA.

National Committee for Clinical Laboratory Standards (NCCLS), 2002b. Development of in vitro susceptibility testing criteria and quality control parameters for veterinary antimicrobial agents $2^{\text {nd }}$ Edition. NCCLS document M 37-A2. NCCLS, Wayne, PA, USA.

National Committee for Clinical Laboratory Standards (2004): Performance standards for antimicrobial disk and dilution susceptibility tests for bacteria isolated from animals; information supplement. NCCLS document M31-S1. NCCLS, Wayne, PA, USA. 
Richter, A., Böttner, A., Goossens, L., Hafez, H.M., Hartmann, K., Kehrenberg, C., Kietzmann, M., Klarmann, D., Klein, G., Krabisch, P., Kühn, T., Luhofer, G., Schulz, B., Schwarz, S., Sigge, C., Waldmann, K.-H., Wallmann, J., Werckenthin, C., 2006. Possible causes of failure of antibiotic therapy in veterinary practice [in German, with English abstract]. Prakt. Tierarzt 87, 624-631.

Roy, O., Hortet, P., Houffschmitt, P., Bousquet, E., 2000a. Efficacy of amoxicillin in liquid feed against an Actinobacillus pleuropneumoniae induced pneumonia in pigs. In: Proceedings of the 8th International Congress of the European Association for Veterinary Pharmacology and Toxicology (EAVPT), 66, Jerusalem., p. 66.

Roy, O., Hortet, P., Frayssinet, L., Bousquet, E., 2000b. Efficacy of amoxicillin administered into drinking water against an Actinobacillus pleuropneumoniae induced pneumonia in pigs. In: Proceedings of the 8th International Congress of the European Association for Veterinary Pharmacology and Toxicology (EAVPT), 66, Jerusalem, p. 108.

Schwarz, S., Böttner, A., Hafez, H.M., Kehrenberg, C., Kietzmann, M., Klarmann, D., Klein, G., Krabisch, P., Kühn, T., Luhofer, G., Richter, A., Traeder, W., Waldmann, K.-H., Wallmann, J., Werckenthin, C., 2003. Antimicrobial susceptibility testing of bacteria isolated from animals: methods for in-vitro susceptibility testing and their suitability with regard to the generation of the most useful data for therapeutic applications [in German, with English abstract]. Berl. Münch. Tierärztl. Wschr. 116, 353-361.

Shryock, T.R., White, D.W., Staples, J.M., Werner, C.S., 1996. Minimum inhibitory concentration breakpoints and disk diffusion inhibitory zone interpretative criteria for 
tilmicosin susceptibility testing against Pasteurella spp. associated with bovine respiratory disease. J. Vet. Diagn. Invest. 8, 337-344.

Sumano, H., Ocampo, L., Vargas, R., Bousquet, E., 2004. Pharamcokinetics of three amoxicillin medicated premixes in pigs. In: Proceedings of the 18th International Pig Veterinary Society (IPVS) Congress, Hamburg, Germany, 2004, Vol. 2, p. 538.

Tanigawa, M., Sawada, T., 2002. Effects of subminimal inhibitory concentrations of Amoxicillin against Actinobacillus pleuropneumoniae. J. Vet. Med. B 49, 513-518.

Tanigawa, M., Sawada, T., 2003. Exposure time-dependent bactericidal activities of amoxicillin against Actinobacillus pleuropneumoniae; an in vitro and in vivo pharmacodynamic model. J. Vet. Med. B 50, 436-442.

Thomas, E., Grandemange, E., Pommier, P., Wessel-Robert, S., Davot, J.L., 2000. Field evaluation of efficacy and tolerance of a $2 \%$ marbofloxacin injectable solution for the treatment of respiratory disease in fattening pigs. Vet. Quart. 22, 131-135.

Vela, A.I., Moreno, M. A., Cebolla, J.A., Gonzalez, S., Latre, M.V., Dominguez, L., Fernandez-Garayzabal, J.F., 2005. Antimicrobial susceptibility of clinical strains of Streptococcus suis isolated from pigs in Spain. Vet. Microbiol. 105, 143-147.

Villa, R., Prandin, E., Montesissa, C., Silvano, C., 1994. Serum protein binding of betalactamine derivatives in farm and domestic animals. In: Proceedings of the 6th International Congress of Veterinary Pharmacology and Toxicology, Edinburgh, UK, pp. 216-217.

Wallmann, J., Schröter, K., Wieler, L.H., Kroker R., 2003. Antibiotic sensitivity in selected veterinary pathogens from sick food animals in Germany: results 2001 from the study model of the national antibiotic resistance monitoring [in German, with English abstract]. Tierärztl. Prax., 31(G), 122-131. 
Wallmann, J., Kaspar, H., Kroker, R., 2004. The prevalence of antimicrobial susceptibility of veterinary pathogens isolated from cattle and pigs: national antibiotic resistance monitoring 2002/2003 of the BVL [in German, with English abstract]. Berl. Münch. Tierärztl. Wschr. 117, 480-492.

Wisselink, H.J., Veldman, K.T., Van den Eede, C., Salmon, S.A., Mevius, D.J., 2006. Quantitative susceptibility of Streptococcus suis strains isolated from diseased pigs in seven European countries to antimicrobial agents licenced in veterinary medicine. Vet. Microbiol. 113, 73-82.

Woolcock, J.B., 1993. Antibiotic susceptibility testing: caeci caecos ducentes. Vet. Rec. $113,125-128$.

Yanedt, A., Lizarazo, V., Rodríguez-Ferri, E.F., Martín de la Fuente, A.J., GutiérrezMartín, C.B., 2006. Evaluation of changes in antimicrobial susceptibility patterns of Pasteurella multocida subsp. multocida isolates from pigs in Spain in 1987-1988 and 2003-2004. Am. J. Vet. Res. 67, 663-668. 
Table 1: Comparative description of the most important pharmacokinetic parameters in pigs after (a) intravenous (i.v.) administration and (b) intramuscular (i.m.) administration of different formulations of amoxicillin at different dose rates

(a)

\begin{tabular}{|c|c|c|c|c|}
\hline Intravenous administration & $\begin{array}{c}\text { AUC } \\
(\mathrm{mg} / \mathrm{h} / \mathrm{l})\end{array}$ & $\begin{array}{l}\text { Vss } \\
(1 / \mathrm{kg})\end{array}$ & $\begin{array}{l}\text { MRT } \\
\text { (h) }\end{array}$ & $\begin{array}{c}\mathrm{Cl}_{\mathrm{B}} \\
(\mathrm{I} / \mathrm{h} / \mathrm{kg})\end{array}$ \\
\hline $\begin{array}{l}\text { Agerso and Friis (1998a) } \\
\text { dose: } 8.6 \mathrm{mg} / \mathrm{kg} \text {, trial } 1\end{array}$ & $23.5 \pm 3.7$ & $0.55 \pm 0.05$ & $1.5 \pm 0.20$ & $0.37 \pm 0.06$ \\
\hline $\begin{array}{l}\text { Agerso and Friis (1998a) } \\
\text { dose: } 8.6 \mathrm{mg} / \mathrm{kg} \text {, trial } 2\end{array}$ & $17.0 \pm 3.4$ & $0.63 \pm 0.17$ & $1.2 \pm 0.20$ & $0.52 \pm 0.10$ \\
\hline $\begin{array}{l}\text { Hernandez et al. (2005) } \\
\text { dose: } 15 \mathrm{mg} / \mathrm{kg}\end{array}$ & $\begin{array}{c}4084 \pm 1011 \\
(\mu \mathrm{g} / \mathrm{min} / \mathrm{ml})\end{array}$ & 0.81 & $1.5 \pm 0.42$ & $\begin{array}{c}3.9 \pm 1.2 \\
(\mathrm{ml} / \mathrm{min} / \mathrm{kg})\end{array}$ \\
\hline $\begin{array}{l}\text { Martinez-Larranaga et al. (2004) } \\
\text { dose: } 20 \mathrm{mg} / \mathrm{kg}\end{array}$ & $67.11 \pm 4.19$ & $1.07 \pm 0.08$ & $\begin{array}{l}3.54 \pm \\
0.43\end{array}$ & $0.30 \pm 0.02$ \\
\hline $\begin{array}{r}\text { Morthorst }(2002) \\
\text { dose: } 20 \mathrm{mg} / \mathrm{kg}\end{array}$ & $23.6 \pm 2.44$ & n.d. ${ }^{*}$ & n.d. & n.d. \\
\hline
\end{tabular}

${ }^{*}$ n.d. $=$ not determined

(b)

\begin{tabular}{|c|c|c|c|c|c|}
\hline $\begin{array}{l}\text { Intramuscular } \\
\text { administration ** }\end{array}$ & $\begin{array}{l}t_{\max } \\
\text { (h) }\end{array}$ & $\begin{array}{c}\mathrm{C}_{\max } \\
(\mu \mathrm{g} / \mathrm{ml})\end{array}$ & $\begin{array}{c}\text { AUC } \\
(\mathrm{mg} / \mathrm{h} / \mathrm{l})\end{array}$ & $\begin{array}{c}\text { MRT } \\
\text { (h) }\end{array}$ & $\begin{array}{l}\text { Bioavaila- } \\
\text { bility } \\
\text { (F) }\end{array}$ \\
\hline $\begin{array}{l}\text { Agerso and Friis (1998a) } \\
\text { dose: } 14.7 \mathrm{mg} / \mathrm{kg}\end{array}$ & $2.0 \pm 0.7$ & $5.1 \pm 0.8$ & $33.1 \pm 3.9$ & $8.8 \pm 2.6$ & $0.82 \pm 0.08$ \\
\hline $\begin{array}{r}\text { Morthorst }(2002) \\
\text { dose: } 20 \mathrm{mg} / \mathrm{kg}\end{array}$ & $\begin{array}{c}1.21 \pm \\
0.73\end{array}$ & $8.54 \pm 3.4$ & $27.8 \pm 10.4$ & n.d. ${ }^{*}$ & 1.18 \\
\hline $\begin{array}{l}\text { Tanigawa and Sawada } \\
\text { (1998) } \\
\text { dose: } 7.5 \mathrm{mg} / \mathrm{kg}\end{array}$ & n.d. & $1.12 \pm 0.45$ & $21.0 \pm 12.0$ & n.d. & n.d. \\
\hline $\begin{array}{l}\text { Agerso and Friis (1998a) } \\
\text { dose: } 14.1 \mathrm{mg} / \mathrm{kg}, \mathrm{LA}^{* * *}\end{array}$ & $1.3 \pm 0.5$ & $1.7 \pm 1.0$ & $47.6 \pm 7.0$ & $\begin{array}{l}66.8 \pm \\
26.2\end{array}$ & $1.26 \pm 0.24$ \\
\hline $\begin{array}{l}\text { Tanigawa and Sawada } \\
\text { (1998), } \\
\text { dose: } 15 \mathrm{mg} / \mathrm{kg}\end{array}$ & n.d. & $2.81 \pm 0.48$ & $42.9 \pm 9.93$ & n.d. & n.d. \\
\hline
\end{tabular}

* n.d. $=$ not determined

** no values for Vss and $\mathrm{Cl}_{\mathrm{B}}$ have been determined in any of these studies

*** formulation with aluminium stearate, long-acting formulation 
Table 2: Comparative description of the most important pharmacokinetic parameters in pigs after peroral (p.o.) administration (by gavage) of different formulations of amoxicillin at different dose rates

\begin{tabular}{|c|c|c|c|c|c|c|c|}
\hline $\begin{array}{l}\text { Peroral } \\
\text { administration }\end{array}$ & $\begin{array}{l}t_{\max } \\
\text { (h) }\end{array}$ & $\begin{array}{c}C_{\max } \\
(\mu \mathrm{g} / \mathrm{ml})\end{array}$ & $\begin{array}{c}\text { AUC } \\
(\mathrm{mg} / \mathrm{h} / \mathrm{l})\end{array}$ & $\begin{array}{l}\text { Vss } \\
(\mathbf{l} / \mathbf{k g})\end{array}$ & $\begin{array}{c}\text { MRT } \\
\text { (h) }\end{array}$ & $\begin{array}{c}\mathrm{Cl}_{\mathrm{B}} \\
(\mathrm{I} / \mathrm{h} / \mathrm{kg})\end{array}$ & $\begin{array}{c}\text { Bioavaila- } \\
\text { bility } \\
\text { (F) }\end{array}$ \\
\hline $\begin{array}{l}\text { Agerso and Friis } \\
\text { (1998a) } \\
\text { dose: } 10.1 \mathrm{mg} / \mathrm{kg} \text { * } \\
\text { trial } 1\end{array}$ & $\begin{array}{c}1.9 \pm \\
0.9\end{array}$ & $1.6 \pm 0.9$ & $6.5 \pm 2.9$ & n.d. & $\begin{array}{c}8.7 \pm \\
6.2\end{array}$ & n.d. & $0.31 \pm 0.15$ \\
\hline $\begin{array}{l}\text { Agerso and Friis } \\
\text { (1998a) } \\
\text { dose: } 10.1 \mathrm{mg} / \mathrm{kg} \\
\text { trial } 2\end{array}$ & $\begin{array}{c}3.6 \pm \\
1.5\end{array}$ & $0.8 \pm 0.3$ & $5.5 \pm 1.5$ & n.d. & $\begin{array}{l}10.4 \\
\pm 1.9\end{array}$ & n.d. & $0.28 \pm 0.08$ \\
\hline $\begin{array}{l}\text { Anadon et al. (2000) } \\
\text { dose: } 20 \mathrm{mg} / \mathrm{kg}\end{array}$ & $\begin{array}{c}0.96 \pm \\
0.18\end{array}$ & $\begin{array}{l}6.76 \pm \\
0.67\end{array}$ & $25.2 \pm 3.6$ & $\begin{array}{c}1.81 \\
\pm \\
0.23\end{array}$ & n.d. & $0.3 \pm 0.03$ & $0.39 \pm 0.08$ \\
\hline $\begin{array}{l}\text { Sumano et al. } \\
(2004) \\
\text { dose: } 20 \mathrm{mg} / \mathrm{kg}^{\star *}\end{array}$ & $\begin{array}{c}1.66 \pm \\
0.02\end{array}$ & $\begin{array}{c}3.07 \pm \\
0.06\end{array}$ & $\begin{array}{c}14.4 \pm \\
0.16\end{array}$ & n.d. & n.d. & n.d. & n.d. \\
\hline $\begin{array}{l}\text { Sumano et al. } \\
\text { (2004) } \\
\text { dose: } 20 \mathrm{mg} / \mathrm{kg} \text {, } \\
\text { conventional } \\
\text { formulation A }\end{array}$ & $\begin{array}{l}1.85 \pm \\
0.16\end{array}$ & $\begin{array}{l}1.53 \pm \\
0.12\end{array}$ & $\begin{array}{c}7.73 \pm \\
0.37\end{array}$ & n.d. & n.d. & n.d. & n.d. \\
\hline $\begin{array}{l}\text { Sumano et al. } \\
\text { (2004) } \\
\text { dose: } 20 \mathrm{mg} / \mathrm{kg} \text {, } \\
\text { conventional } \\
\text { formulation B }\end{array}$ & $\begin{array}{l}1.25 \pm \\
0.53\end{array}$ & $\begin{array}{l}1.67 \pm \\
0.24\end{array}$ & $\begin{array}{c}7.21 \pm \\
0.24\end{array}$ & n.d. & n.d. & n.d. & n.d. \\
\hline
\end{tabular}

* fasting pigs

** special formulation 
Table 3: Comparative description of the most important pharmacokinetic parameters in pigs after peroral (p.o.) administration (in feed or drinking water) of different formulations of amoxicillin at different dose rates

\begin{tabular}{|c|c|c|c|c|c|c|c|}
\hline $\begin{array}{l}\text { peroral } \\
\text { administration }\end{array}$ & $\begin{array}{l}t_{\max } \\
\text { (h) }\end{array}$ & $\begin{array}{c}C_{\max } \\
(\mu g / m l)\end{array}$ & $\begin{array}{c}\text { AUC } \\
(\mathrm{mg} / \mathrm{h} / \mathrm{l})\end{array}$ & $\begin{array}{l}\text { Vss } \\
(1 / \mathbf{k g})\end{array}$ & $\begin{array}{l}\text { MRT } \\
\text { (h) }\end{array}$ & $\begin{array}{c}\mathrm{Cl}_{\mathrm{B}} \\
(\mathrm{I} / \mathrm{h} / \mathrm{kg})\end{array}$ & $\begin{array}{c}\text { Bioavaila- } \\
\text { bility } \\
\text { (F) }\end{array}$ \\
\hline $\begin{array}{l}\text { Anadon et al. } \\
(2000)^{*} \\
\text { dose: } 20 \mathrm{mg} / \mathrm{kg}\end{array}$ & $\begin{array}{c}0.96 \pm \\
0.18\end{array}$ & $\begin{array}{l}6.76 \pm \\
0.67\end{array}$ & $\begin{array}{l}25.2 \pm \\
3.6\end{array}$ & $\begin{array}{l}1.81 \pm \\
0.23\end{array}$ & n.d. & $\begin{array}{l}0.3 \pm \\
0.03\end{array}$ & $0.39 \pm 0.08$ \\
\hline $\begin{array}{l}\text { Anfossi et al. } \\
(2002)^{\star *} \\
\text { dose: } 50 \mathrm{mg} / \mathrm{kg} \\
\text { microgranular } \\
\text { formulation }\end{array}$ & $\begin{array}{c}2.5 \pm \\
1.37\end{array}$ & $4.2 \pm 2.41$ & $\begin{array}{c}18.9 \pm \\
9.18\end{array}$ & n.d. & $\begin{array}{c}4.01 \pm \\
0.84\end{array}$ & n.d. & n.d. \\
\hline $\begin{array}{l}\text { Anfossi et al. } \\
(2002)^{\star *} \\
\text { dose: } 50 \mathrm{mg} / \mathrm{kg} \\
\text { microgranular } \\
\text { formulation }\end{array}$ & $\begin{array}{c}1.78 \pm \\
0.36\end{array}$ & $\begin{array}{c}3.36 \pm \\
1.36\end{array}$ & $\begin{array}{c}14.15 \pm \\
5.43\end{array}$ & n.d. & $\begin{array}{c}4.02 \pm \\
0.75\end{array}$ & n.d. & n.d. \\
\hline $\begin{array}{l}\text { Anfossi et al. } \\
(2002)^{\star *} \\
\text { dose: } 50 \mathrm{mg} / \mathrm{kg}\end{array}$ & $\begin{array}{c}2.06 \pm \\
1.63\end{array}$ & $\begin{array}{c}2.85 \pm \\
0.74\end{array}$ & $\begin{array}{c}12.11 \pm \\
2.4\end{array}$ & n.d. & $\begin{array}{c}3.86 \pm \\
0.81\end{array}$ & n.d. & n.d. \\
\hline $\begin{array}{l}\text { Hernandez et al. } \\
(2005)^{\star *} \\
\text { dose: } 15 \mathrm{mg} / \mathrm{kg}\end{array}$ & $\begin{array}{l}5.8 \pm \\
2.3\end{array}$ & $\begin{array}{l}0.76 \pm \\
0.05\end{array}$ & n.d. & n.d. & & n.d. & $0.11 \pm 0.05$ \\
\hline $\begin{array}{l}\text { Martinez- } \\
\text { Larranaga et al. } \\
(2004)^{\star *} \\
\text { dose: } 20 \mathrm{mg} / \mathrm{kg}\end{array}$ & $\begin{array}{c}0.97 \pm \\
0.29\end{array}$ & $\begin{array}{c}7.37 \pm \\
0.42\end{array}$ & $\begin{array}{c}27.4 \pm \\
4.93\end{array}$ & $\begin{array}{c}1.35 \pm \\
0.2\end{array}$ & $\begin{array}{c}4.47 \pm \\
0.30\end{array}$ & n.d. & 0.41 \\
\hline $\begin{array}{l}\text { Morthorst } \\
(2002)^{\star \star *} \\
\text { dose: } 20 \mathrm{mg} / \mathrm{kg}\end{array}$ & $\begin{array}{l}0.55 \pm \\
0.85\end{array}$ & $\begin{array}{l}21.6 \pm \\
34.5\end{array}$ & $\begin{array}{c}21.4 \pm \\
12.9\end{array}$ & n.d. & n.d. & n.d. & 0.98 \\
\hline
\end{tabular}


Table 4: Distribution of MIC values of ampicillin or amoxicillin among relevant porcine respiratory tract pathogens

\begin{tabular}{|c|c|c|c|c|c|c|c|c|c|c|c|}
\hline \multirow[t]{2}{*}{ Bacteria } & \multirow{2}{*}{$\begin{array}{l}\text { Time } \\
\text { span }\end{array}$} & \multirow[t]{2}{*}{ Country } & \multirow{2}{*}{$\begin{array}{l}\text { No. of } \\
\text { strains } \\
\text { tested }\end{array}$} & \multicolumn{5}{|c|}{ MIC values $(\mu \mathrm{g} / \mathrm{ml})$} & \multirow[t]{2}{*}{$\mathrm{MIC}_{50}$} & \multirow[t]{2}{*}{$\mathrm{MIC}_{90}$} & \multirow[t]{2}{*}{ Reference } \\
\hline & & & & $\leq 0.25$ & 0.5 & 1 & 2 & $\geq 4$ & & & \\
\hline A. pleuropneumoniae & $\begin{array}{l}1997-2004 \\
2002-2004 \\
2004-2005\end{array}$ & $\begin{array}{l}\text { Spain } \\
\text { Switzerland } \\
\text { Germany }\end{array}$ & $\begin{array}{c}229 \\
83 \\
124\end{array}$ & $\begin{array}{c}28 \\
66 \\
114\end{array}$ & $\begin{array}{c}154 \\
12 \\
4\end{array}$ & $\begin{array}{l}10 \\
2 \\
0\end{array}$ & $\begin{array}{l}3 \\
0 \\
0\end{array}$ & $\begin{array}{c}34 \\
3 \\
6\end{array}$ & $\begin{array}{l}0.5 \\
0.25 \\
0.25\end{array}$ & $\begin{array}{l}\geq 64 \\
0.5 \\
0.25\end{array}$ & $\begin{array}{l}\text { Gutierrez-Martin et al. (2006) * } \\
\text { Matter et al. (2007) } \\
\text { Wallmann (unpublished data) }\end{array}$ \\
\hline H. parasuis & $\begin{array}{l}1998-2002 \\
1995-2005 \\
2002-2004\end{array}$ & $\begin{array}{l}\text { Denmark } \\
\text { UK } \\
\text { Spain }\end{array}$ & $\begin{array}{l}52 \\
30 \\
30\end{array}$ & $\begin{array}{c}0 \\
22 \\
6\end{array}$ & $\begin{array}{l}0 \\
3 \\
2\end{array}$ & $\begin{array}{c}52 \\
1 \\
2\end{array}$ & $\begin{array}{l}0 \\
1 \\
2\end{array}$ & $\begin{array}{c}0 \\
3 \\
17\end{array}$ & $\begin{array}{c}1 \\
0.5 \\
16\end{array}$ & $\begin{array}{r}1 \\
1 \\
\geq 32\end{array}$ & $\begin{array}{l}\text { Aarestrup et al. (2004) } \\
\text { Martín de la Fuente et al. (2007) } \\
\text { Martín de la Fuente et al. (2007) }\end{array}$ \\
\hline B. bronchiseptica & $\begin{array}{l}2000-2003 \\
2002-2003 \\
2004-2005\end{array}$ & $\begin{array}{l}\text { Germany } \\
\text { Germany } \\
\text { Germany }\end{array}$ & $\begin{array}{l}349 \\
138 \\
241\end{array}$ & $\begin{array}{l}0 \\
0 \\
0\end{array}$ & $\begin{array}{l}0 \\
0 \\
0\end{array}$ & $\begin{array}{c}12 \\
0 \\
0\end{array}$ & $\begin{array}{l}6 \\
3 \\
1\end{array}$ & $\begin{array}{l}331 \\
135 \\
240\end{array}$ & $\begin{array}{c}8 \\
16 \\
16\end{array}$ & $\begin{array}{l}16 \\
16 \\
32\end{array}$ & $\begin{array}{l}\text { Kadlec et al. (2004) } \\
\text { Wallmann et al. (2004) } \\
\text { Wallmann (unpublished data) }\end{array}$ \\
\hline P. multocida & $\begin{array}{c}2001 \\
2002-2003 \\
2004-2005 \\
1987-1988 \\
2003-2004\end{array}$ & $\begin{array}{l}\text { Germany } \\
\text { Germany } \\
\text { Germany } \\
\text { Spain } \\
\text { Spain }\end{array}$ & $\begin{array}{c}176 \\
442 \\
287 \\
63 \\
132\end{array}$ & $\begin{array}{c}170 \\
391 \\
275 \\
62 \\
119\end{array}$ & $\begin{array}{c}1 \\
13 \\
2 \\
0 \\
6\end{array}$ & $\begin{array}{l}0 \\
7 \\
1 \\
0 \\
1\end{array}$ & $\begin{array}{l}1 \\
6 \\
0 \\
0 \\
0\end{array}$ & $\begin{array}{c}4 \\
25 \\
9 \\
1 \\
6\end{array}$ & $\begin{array}{l}0.12 \\
\leq 0.12 \\
0.12 \\
\leq 0.25 \\
\leq 0.25\end{array}$ & $\begin{array}{c}0.25 \\
0.5 \\
0.25 \\
\leq 0.25 \\
\leq 0.25\end{array}$ & $\begin{array}{l}\text { Wallmann et al. (2003) } \\
\text { Wallmann et al. (2004) } \\
\text { Wallmann (unpublished data) } \\
\text { Yanedt et al. (2006) } \\
\text { Yanedt et al. (2006) }\end{array}$ \\
\hline S. suis & $\begin{array}{l}2004-2005 \\
1999-2001\end{array}$ & $\begin{array}{l}\text { Germany } \\
\text { Spain }\end{array}$ & $\begin{array}{l}312 \\
151\end{array}$ & $\begin{array}{l}307 \\
145\end{array}$ & $\begin{array}{l}1 \\
2\end{array}$ & $\begin{array}{l}0 \\
2\end{array}$ & $\begin{array}{l}2 \\
1\end{array}$ & $\begin{array}{l}2 \\
1\end{array}$ & $\begin{array}{l}\leq 0.03 \\
\leq 0.25\end{array}$ & $\begin{array}{l}0.06 \\
\leq 0.25\end{array}$ & $\begin{array}{l}\text { Wallmann (unpublished data) } \\
\text { Vela et al. (2005)* }\end{array}$ \\
\hline
\end{tabular}

\footnotetext{
* In these studies, susceptibility to amoxicillin (instead of susceptibility to ampicillin) was tested.
} 